\title{
A Review: The Effect of Plant Growth Regulators on Micropropagation of Aglaonema sp.
}

\author{
Meutia Zahara*1,2, Cho Cho Win ${ }^{3}$ \\ ${ }_{1}^{1}$ Postgraduate Program of Public Health, Universitas Muhammadiyah Aceh \\ Jl. Muhammadiyah No 91, Batoh, 23245, Banda Aceh, Indonesia \\ ${ }^{2}$ Department of Biology, Islamic Faculty, Universitas Muhammadiyah Aceh \\ Jl. Muhammadiyah No 91, Batoh, 23245, Banda Aceh, Indonesia \\ ${ }^{3}$ National Project Coordinator, Farming System Sustainability Project - Myanmar \\ Nay Pyi Taw, 15011, Myanmar \\ *Corresponding author: teeya_razali@yahoo.co.id; meutia.zahara@unmuha.ac.id
}

\section{ARTICLE HISTORY}

$\begin{array}{ll}\text { Received } & : 22 \text { August } 2020 \\ \text { Revised } & : 12 \text { September } 2020 \\ \text { Accepted } & : 25 \text { September } 2020\end{array}$

\section{KEYWORDS}

Micropropagation;

Araceae;

Aglaonema sp.;

Ornamental Plants,

\begin{abstract}
Nowadays, Aglaonema sp. becomes very famous in Indonesia. especially during the pandemic covid-19. Many people tend to stay home to stop the spreading of the virus. One of the activities can be done during staying home is growing the plants as well as ornamental plants. Aglaonema sp. is one of important and well-known foliage ornamental plants in Indonesia, commonly called as "Sri Rezeki". The generative or sexual reproduction of Aglaonema sp. is difficult and it contains some endogenous pathogen. The common propagation techniques are by cutting and seed which is risky in the spreading of the pathogen. Micropropagation is an advance technique to produce a large number of plants in a short time and pathogen-free transplant. This manuscript endeavour to include some important investigations and studies on the use of the Plant Growth Regulators (PGRs) on the Aglaonema sp. micropropagation
\end{abstract}

This is an open access article under the CC-BY-SA license.

\section{INTRODUCTION}

Some ornamental plants in the world have accompanied the historical value, used to use as an expression symbol of wellbeing and the beauty of landscape. As in Asia, Africa and Latin America using ornamental plants for the tradition of brighten ceremonies and national day celebrations, this condition increases the ornamental plants popularity. Currently, the most rapid expanding ornamental plants are foliage plants for indoor use, bedding and garden plants (Mariani et al., 2011). Aglaonema consists of many important and demanding cultivar of foliage plants due to their beautiful shape, colorful, drought tolerance and low relative humidity (Yeh et al., 2007).

Nowadays, Aglaonema sp. becomes very famous in Indonesia, especially during the pandemic covid-19. Many people tend to stay home to stop the spreading of the virus, one of the activities can be done during stay home is growing the plants as well as ornamental plants. Aglaonema sp. is one of important dan well known foliage ornamental plants in Indonesia, commonly called as "Sri Rezeki" and comprised more than 21 species (Dikayani et al., 2013). This genus also known as Chinese Evergreen, a monocot which is belongs to Araceae family and spreads around southeastern Asia, northeastern India, southern China, Indonesia, Malaysia, and New Guinea (Chen et al., 2003). This foliage ornamental plant has been produced due to its attractive foliage shape, easy to cultivated, low light tolerance and low relative humidity (Henny, 2000; Chen et al., 2002). New cultivars have been released continuously to maintain the popularity of the plants (Chen et al., 2002).

Due to the non-simultaneous flowering and short life cycle of the pollen make the sexual reproduction difficult, so most of Aglaonema sp. have been propagated by cutting the rooting part from nodes or shoot basal division as the basic method (Barakat and Gaber, 2018). Another condition is the problem with endogenous pathogen that may stay in the vascular bundle tissue and may spread through the cutting method (Chase, 1997). Micropropagation is an advanced propagation method through vegetative way to produce large amount of seedling in a short time and pathogen-free transplants. This method starting with growing plantlets on a medium contains water and nutrition under aseptic condition (Chen, 2007; Chen et al., 2013; Chen 2015).

\section{GENERAL INFPORMATION}

Aglaonema is a genus from monocots that belongs to Araceae family consists of 21 species that accepted and published (Table 1). These perennial herbs have an erect and decumbent stem which can grow along the ground and may rooting around the nodes. Containing the most 
beautiful shape and colors of the leaves, it shows very good colors combination, such as green and orange, green and red, green and yellow, green and white, green and pink, etc (Mariani et al., 2011). Most of Aglaonema's species have white roots, $1-5 \mathrm{~cm}$ thick stem, can reach until $50 \mathrm{~cm}$ in height, the inflorescence type called a spadix (Mariani et al., 2011), the color of the flower mostly white and normally bloom during March-July. Aglaonema also contains come toxic agent named calcium oxalate crystal to protect themselves from the enemy, this agent will cause some irritation on the skin.

\begin{tabular}{ll}
\multicolumn{2}{l}{ Scientific classification } \\
Kingdom & : Plantae \\
Subkingdom & : Tracheobionta \\
Superdivision & : Spermathophyta \\
Division & $:$ Magnoliophyta \\
Class & $:$ Liliopsida \\
Ordo & $:$ Alismatales \\
Family & $:$ Araceae \\
Genus & $:$ Aglaonema \\
Species & $:$ Aglaonema sp.
\end{tabular}

Scientific classification

Kingdom : Plantae

Superdivision : Spermathophyta

Division : Magnoliophyta

Class : Liliopsida

Ordo : Alismatales

Species : Aglaonema sp.

Table 1. Accepted species from Araceae family (Govaerts et al., 2002)

\begin{tabular}{|c|c|c|c|}
\hline No & Spesies & Origin & Leaves color combination \\
\hline 1 & Aglaonema brevispathum & Indochina & Light-dark green \\
\hline 2 & Aglaonema chermsiriwattanae & Thailand & Greenish white \\
\hline 3 & Aglaonema cochinchinense & Vietnam, Cambodia, Thailand, and Malaysia & Green -white \\
\hline 4 & Aglaonema commutatum & Philippines and Indonesia & Green-white \\
\hline 5 & Aglaonema cordifolium & Mindanao, Philippines & Green \\
\hline 6 & Aglaonema costatum & Malaysia and Indochina & Green-white \\
\hline 7 & Aglaonema densinervium & Philippines and Indonesia & Green \\
\hline 8 & Aglaonema flemingianum & Terengganu & Dark green \\
\hline 9 & Aglaonema hookerianum & Bangladesh and Myanmar & Green-light yellow \\
\hline 10 & Aglaonema marantifolium & Indonesia and New Guinea & Green-white \\
\hline 11 & Aglaonema modestum & Japan, Bangladesh, Indochina, Southern-china & Green-white \\
\hline 12 & Aglaonema nebulosum & Malaysia and Indonesia & Green-white \\
\hline 13 & Aglaonema nitidum & Malaysia, Indonesia and Indochina & Green-grey \\
\hline 14 & Aglaonema ovatum & Laos, Thailand, Vietnam & Green \\
\hline 15 & Aglaonema philippinense & Philippines and Indonesia & Greenish white \\
\hline 16 & Aglaonema pictum & Indonesia & Dark green-light green-white \\
\hline 17 & Aglaonema pumilum & Myanmar and Thailand & Dark green-white \\
\hline 18 & Aglaonema roebelinii & Philippines & Green-white \\
\hline 19 & Aglaonema rotundum & Indonesia & Dark purple-green and dark purple-red \\
\hline 20 & Aglaonema tricolor & Philippines & Pink-green-white \\
\hline 21 & Aglaonema vittatum & Indonesia & Green-white \\
\hline
\end{tabular}

\section{MICROPROPAGATION OF Aglaonema sp.}

Micropropagation is the tissue culture technique application to propagate plants under aseptic condition. This technique could be done to produce large amount of pathogen-free and uniform transplants in a short time and in a small place (Chen et al., 2013; Chen 2015). Some protocols have been conducted for the micropropagation of Aglaonema sp., but still not meet the purposes with Aglaonema, mainly due to the difficulty to maintain the aseptic culture condition (Chen and Yeh, 2007), low rate of shoot multiplication reported by Chen and Yeh (2007) as well as in the research conducted by Zhang et al.
(2004), and lack of technical information on micropropagation procedure of Aglaonema (Mariani et al., 2011).

In vitro technique could be done for physiologically uniform of plant production and rapid multiplication. In many micropropagation's research conducted with high number of treatments, using the plant growth regulators (PGRs) and some dosages were tested to obtain a good propagation protocol. Endogenous microbial contamination is the most serious problem in micropropagation of ornamental aroids, including Aglaonema (Chen and Yeh, 2007). 
The use of PGR combination on the medium for Aglaonema sp. micropropagation was conducted by many researchers for some purposes. Fang et al. (2013) conducted a research with Aglaonema 'Lady valentine' as the popular red cultivar that were cultured on the Murashige and Skoog (MS) medium supplemented with PGRs to develop an efficient micropropagation procedure through adventitious shoot induction and proliferation. The single nodal stem with an axillary bud were cultured on $10 \mathrm{ml}$ MS medium supplemented with $32 \mathrm{mg}$. $\mathrm{l}^{-1}$ gentamicin, $8 \mathrm{mg} . \mathrm{l}^{-1}$ tetracycline and $4 \mathrm{mg}^{-\mathrm{l}^{-1}}$ chloramphenicol. The best growth of axillary obtained when $10 \mathrm{mg}^{-1}$ of 6-benzyladenine (BA) supplemented to the medium. Afterwards, the single nodal stem produced were cultured on MS medium supplemented with PGR combination; naphthalene acetic acid (NAA) and thidiazuron (TDZ) (Table 2). The results showed that the average of 10.9 adventitious shoots per stem obtained from the combination of $0.5 \mathrm{mg} . \mathrm{l}^{-1} \mathrm{NAA}$ and $2 \mathrm{mg}$. $\mathrm{l}^{-1} \mathrm{TDZ}$. Later on, small shoots formation was culture on the medium supplemented with $\mathrm{BA}$ and $\mathrm{GA}_{3}$. The concentration of $0.5-5 \mathrm{mg}^{-1}$ of BA showed more effective for shoot proliferation and elongation compared to $0.5 \mathrm{mg}$. $\mathrm{I}^{-1} \mathrm{GA}_{3}$ treatments (Fang et al., 2013). After three months of culture, the longest shoot $(2.69 \mathrm{~cm})$ were obtained from $5 \mathrm{mg} \cdot \mathrm{l}^{-1} \mathrm{BA}$.

Table 2. The effect of NAA and TDZ combination on the adventitious shoot induction performance in Aglaonema "Lady Valentine" stem nodal segments after three months culture (Fang et al., 2013)

\begin{tabular}{|c|c|c|c|c|}
\hline \multirow{2}{*}{ No } & \multicolumn{2}{|c|}{ PGR (mg. $\mathrm{l}^{-1}$ ) } & \multirow{2}{*}{$\begin{array}{l}\% \text { Adventitious } \\
\text { shoot induction }\end{array}$} & \multirow{2}{*}{$\begin{array}{c}\text { Number of adventitious } \\
\text { shoots induced }\end{array}$} \\
\hline & NAA & TDZ & & \\
\hline 1 & 1 & 0 & $16.1 \pm 6.1^{b}$ & $0.2 \pm 0.0^{c}$ \\
\hline 2 & 0.1 & 0.5 & $88.9 \pm 11.1^{\mathrm{a}}$ & $4.5 \pm 0.9 \mathrm{bc}$ \\
\hline 3 & 0.1 & 1 & $68.6 \pm 11.5^{a}$ & $8.9 \pm 2.0^{\mathrm{ab}}$ \\
\hline 4 & 0.25 & 0.5 & $25.0 \pm 8.4^{b}$ & $0.3 \pm 0.1^{\mathrm{c}}$ \\
\hline 5 & 0.25 & 1 & $25.0 \pm 8.4^{\mathrm{b}}$ & $0.7 \pm 0.5^{c}$ \\
\hline 6 & 0.25 & 2 & $80.2 \pm 8.8^{a}$ & $9.8 \pm 1.5^{\mathrm{a}}$ \\
\hline 7 & 0.5 & 1 & $63.9 \pm 13.9^{a}$ & $7.0 \pm 1.2^{\mathrm{ab}}$ \\
\hline 8 & 0.5 & 2 & $61.1 \pm 10.4^{\mathrm{a}}$ & $10.9 \pm 2.5^{\mathrm{a}}$ \\
\hline 9 & 1 & 2 & $59.0 \pm 3.5^{\mathrm{a}}$ & $9.0 \pm 1.8^{\mathrm{ab}}$ \\
\hline
\end{tabular}

The research conducted with Aglaonema 'White Tip' cultivar showed that each nodal formed six shoots after cultured on MS medium supplemented with $6.8 \mathrm{mg}^{\mathrm{l}^{-1} \mathrm{BA}}$ after 60 days of culture (Chen and Yeh, 2007). Direct shoot formation induced on Aglaonema 'White Tip' after the explants cultured on the medium supplemented with 1.1-2.2 $\mathrm{mg}^{-1}$ dicamba (3,6-dichloro-2-methoxybenzoic acid) and $2.2 \mathrm{mg}^{-1} \mathrm{l}^{-1} \mathrm{TDZ}$ (Yeh, 2007). While in Aglaonema commutatum, an average of 4.1 shoots formed every month from the stem which were cultured on the medium supplemented with $2.5 \mathrm{mg}$. $\mathrm{l}^{-1} \mathrm{BA}$ and $0.05-0.1 \mathrm{mg}$. $\mathrm{l}^{-1} \mathrm{NAA}$ (Zhang et al., 2004). Aglaonema var. Lipstick research showed that after 16 weeks of culture formed callus formation by combination treatment of $5 \mathrm{mg}^{\mathrm{l}^{-1} \mathrm{IAA} \text { and } 5}$ mg. $\mathrm{l}^{-1} \mathrm{BAP}$ as well as in the combination of $8 \mathrm{mg}^{-1} \mathrm{l}^{-1}$ IAA and $5 \mathrm{mg} . \mathrm{l}^{-1} \mathrm{BAP}$, the color of the callus are clear, globular shape and friable textures (Dewi et al., 2012).
Aglaonema widuri or Aglaonema red peacock were micropropagated on MS medium supplemented with three cytokinin (BA, TDZ and 2-ip) with one auxin (NAA) aimed to develop a protocol for high frequency multiplication (Fig.1). The highest shoot proliferation rate obtained in the combination of $3 \mathrm{mg}^{-1} \mathrm{l}^{-1} \mathrm{BA}$ and $0.2 \mathrm{mg}^{\mathrm{l}^{-1}}$ NAA $(6.00$ number of shoots and $7.75 \mathrm{~cm}$ in length/explant), the maximum nodes formed by the combination of $4.00 \mathrm{mg} . \mathrm{l}^{-1} \mathrm{BA}+0.10 \mathrm{mg}$. $\mathrm{l}^{-1} \mathrm{NAA} 0.50 \mathrm{mg}$. $\mathrm{l}^{-1}$ TDZ (13.25/explant), The largest leaf number formed in the combination of $3.50 \mathrm{mg} . \mathrm{l}^{-1} \mathrm{BA}$ and $0.20 \mathrm{mg} . \mathrm{l}^{-1} \mathrm{NAA}$, while the maximum root development obtained from the combination of $3.00 \mathrm{mg} . \mathrm{l}^{-1}$ and $0.20 \mathrm{mg}$. $\mathrm{l}^{-1} \mathrm{NAA}$. The most suitable plant growth regulators for Aglaonema widuri tissue culture was the combination of $3.50 \mathrm{mg}^{-1} \mathrm{BA}$ and $0.20 \mathrm{mg} . \mathrm{l}^{-1}$ NAA (Kaviani et al., 2018). 

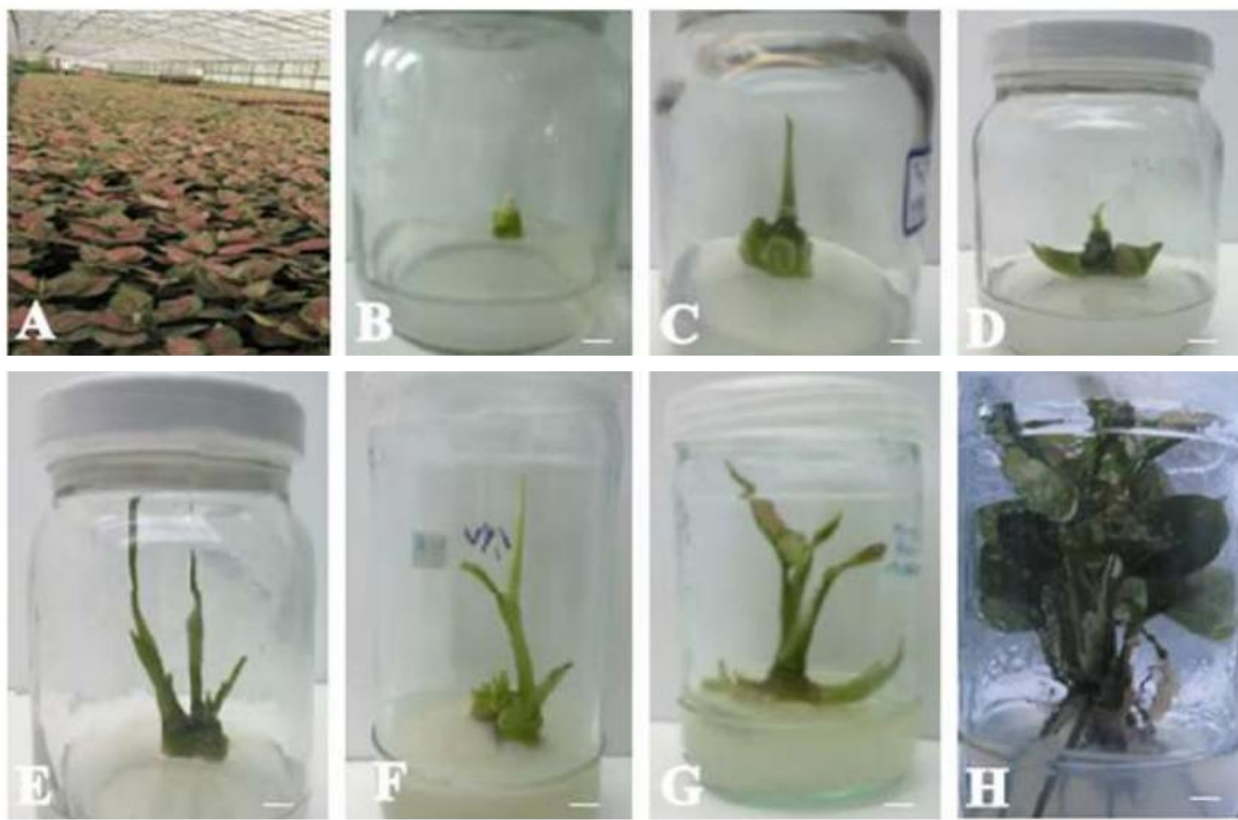

Figure 1. The effect of PGRs on the proliferation and elongation of Aglaonema widuri: A. Mother plants growing in the greenhouse, B. Shoot tips cultivated on the medium containing PGRs, C.D.E and F. Development of the explants, G. Shoot proliferation, leaf induction and growth, H. Plantlets with shoots and roots proliferation after three months of culture (Kaviani et al., 2018).

\section{CONCLUSION}

Aglaonema is monocots that's belonging to the Araceae family and consist of around 21 species. The popularity of this genus is attributed by their beautiful shape and color of the leave, easy to grow, low light tolerance and low humidity. The rooting of cutting of basal shoots are the main method of cultivating the Aglaonema sp., this method is high risk of pathogen transfer since the endogenous pathogen as the main problem from this genus. Some micropropagation techniques were conducted to cultivated the Aglaonema sp. in a short time, with a large number of seedlings in a small place and to produce plant-free pathogen, the use of the PGRs combination is one of the methods in micropropagation. Further research needed to complete the protocols of the Aglaonema sp. micropropagation.

\section{REFERENCES}

Barakat, A. A., \& Gaber, M. K. (2018). Micropropagation and ex vitro acclimatization of aglaonema plants. Sciences, 8(04), 1425-1436.

Chase, A.R. (1997). Foliage plant diseases: diagnose and control. American Phytopathological Society (8-11)

Chen, J., Henny, R. J., \& McConnell, D. B. (2002). Development of new foliage plant cultivars. Trends in new crops and new uses. ASHS Press, Alexandria, VA, 466-472.

Chen, J., McConnell, D. B., Henny, R. J., \& Everitt, K. C. (2003). Cultural guidelines for commercial production of interiorscape Aglaonema. EDIS, 2003(18).

Chen, C. (2007). In situ measurement of microclimate for the plantlets cultured in vitro. Biosystems engineering, 95(3), 413-423.

Chen, W. L., \& Yeh, D. M. (2007). Elimination of in vitro contamination, shoot multiplication, and ex vitro rooting of Aglaonema. Hort. Science, 42(3), 629-632.

Chen, C. (2015). Application of growth models to evaluate the microenvironmental conditions using tissue culture plantlets of Phalaenopsis Sogo Yukidian 'V3'. Scientia Horticulturae, 191, 25-30.

Dewi, I. S., Wahyuni, D. K., \& Purnobasuki, H. (2012). PERKEMBANGAN KULTUR DAUN Aglaonema sp. var Siam Pearl, Aglaonema sp. var. Lady Valentin dan Aglaonema sp. var. Lipstik DENGAN PERLAKUAN ZAT PENGATUR TUMBUH IAA DAN BAP. Berkala Penelitian Hayati, 17(2), 197-203.

Dikayani, D., Hidayat, C., Chaidir, L., \& Nuraini, A. (2019, July). INDUKSI MATA TUNAS Aglaonema VARIETAS SIAM PEARL DENGAN MEDIA DASAR DAN BAP (6-Benzyl Amino Purine) SECARA IN VITRO. In Prosiding Seminar Nasional Agroteknologi (Vol. 1, pp. 122-131).

Fang, J. Y., Hsu, Y. R., \& Chen, F. C. (2013). Development of an efficient micropropagation procedure for Aglaonema 'Lady Valentine'through adventitious shoot induction and proliferation. Plant Biotechnology, 13-0618.

Govaerts, R., Frodin, D. G., \& Bogner, J. (2002). World checklist and bibliography of Araceae (and Acoraceae). Royal Botanic Gardens.

Henny, R. J. (2000). Breeding ornamental aroids. Breeding ornamental plants. Timber Press, Portland, OR, 121-132.

Kaviani, B., Sedaghathoor, S., Safari Motlagh, M. R., \& Rouhi, S. (2019). Influence of plant growth regulators (BA, TDZ, 2-iP and NAA) on micropropagation of Aglaonema widuri. Plant Physiology, 9(2), 2709-2718.

Mariani, T. S., Fitriani, A., da Silva, J. T., Wicaksono, A., \& Chia, T. F. (2011). Micropropagation of Aglaonema using axillary shoot explants. Int J Basic Appl Sci, 11(1), 46-53.

Wahyuni, D. K., Prasetyo, D., \& Hariyanto, S. (2014). Perkembangan Kultur Daun Aglaonema sp. dengan Perlakuan Kombinasi Zat Pengatur Tumbuh NAA dan 2, 4-D dengan BAP (The Leaf Culture Development of Aglaonema sp. Treated by Combination of NAA, 2, 
4-D and BAP as Growth Regulators). Jurnal Bios Logos, 4(1).

Yeh, D. M., Yang, W. J., Chang, F. C., Chung, M. C., Chen, W. L., \& Huang, H. W. (2007, December). Breeding and micropropagation of Aglaonema. In International Conference on Quality Management in
Supply Chains of Ornamentals 755 (pp. 93-98).

Zhang, S., Jiang, R., \& Zhou, H. (2004). Study on rapid propagation of Aglaonema commutatum cv.'Golden Jewelry.'. Chin Agr Sci Bull, 20, 39-40. 